„, O R B I S L I N G UAR UM “, VOLUME 20 , ISS U E 1

DOI: https://doi.org/10.37708/ezs.swu.bg.v20i1.8

\title{
THE PSYCHOLINGUISTIC BASIS OF MEDIA NEOLOGIZATION CAUSED BY COVID-19
}

\author{
Dmytro SYZONOV \\ Taras Shevchenko National University of Kyiv, Ukraine \\ E-mail:dm_sizonov@ukr.net \\ Olga ZLOTNYK-SHAGINA \\ Taras Shevchenko National University of Kyiv, Ukraine \\ E-mail: ozlotnik@bigmir.net \\ Oleksandr KOZYNETS \\ National Pedagogical Dragomanov University, Ukraine \\ E-mail: o.v.kozynets@npu.edu.ua
}

\begin{abstract}
The article discusses the psycholinguistic reasons for the appearance of new language units in the Ukrainian language during the COVID-19 pandemic, theso-called "infodemic" (Zarocostas 2020). In a short time, under the influence of extralinguistic factors, language innovations associated with COVID-19 have entered a wide range of media sources, the search for the reasons how these innovations function is the goal of analysis of both media and psycholinguistics. Three methodological bases were chosen, which helped identify the degree of appropriateness of the use of new words in a specific media context. During the pandemic, the media remains the main source of information: on the one hand, the media has a responsibility to inform promptly and truthfully, on the other hand, the degree of misinformation is increasing. Based on this, language innovations appear as psychological markers of time, allusively linked to the pandemic. We assume that the psychological opposition "trust / mistrust" to information also affects the appearance of neologisms, because they actually reflect the mood of society, and therefore the demand for language innovations will be particularly logical in the course of social transformations (as demonstrated by the comparative characteristics of the search engine at the initial stage and at the peak of the COVID-19 pandemic).
\end{abstract}

$\underset{\text { KEYWORDS: }}{\text { linguistics, }}$ psycholinguistics, language neologization, media resource, media

\section{Introduction}

Since the World Health Organization 2020 recognized COVID-19 as a pandemic, a lot of research has been published on the course and causes of the disease (World Health Organization, 2020). There is even a new phenomenon in the modern media space to mark the pandemic in the information age - infodemic (Zarocostas, 2020; Cifuentes-Faura, 2020). Today, medical scientific publications on this problem remain particularly frequent, which is logical in the context of the value of new knowledge for the treatment of the disease. However, there is practically no analysis of the verbal portrait of the pandemic in scientific interpretations. This also applies to media communication, where categories related to COVID-19 are formed and actively function. Individual articles relate to: audience response to COVID-19 in social internet networks and analysis of media literacy in the flow of information about the virus (Zhong, Luo, Li, H., Zhang, Liu, Li, W.\& Li, Y., 2020), the culture of perception of information about COVID-19 in the press (Hernández-García \& Giménez-Júlvez, 2020; Garfin, Silver \& Holman, 2020), a speech resource related to coronavirus (Shymanskaya, 2020), the reasons for the spread of fake news during COVID-19 (Neto, Gomes, Porto, Rafael, Fonseca \& Nascimento, 2020), etc. Screening of student audience experiences during a pandemic the COVID-19 was conducted in (Schiff, Zasiekina, Pat-Horenczyk \& Benbenishty, 2020). Interesting is the study on COVID-19 telegenesis, considered both from the standpoint of biomedicine and from the standpoint of psychology (Zhou, Snoswell, Harding, Bambling, Edirippulige, Bai \& Smith, 2020). Separate psychological and psycholinguistic studies already took place before the 2019 pandemic (Peter, Rossmann \& Keyling, 2014; Jones, Garfin, Holman \& Silver, 2016), the purpose of which was to predict the risks of the population in the post-period of severe social disasters. It should be noted that the problems associated with psychological recovery after socio-economic crises are significantly different from those associated with recovery from medical crises. We assume that the way out of the crisis (both socioeconomic and medical) caused by COVID-19 will also be difficult during the Digital Age. In this 
context, media communication tools should help, becoming the main source of information about the real situation around us. Therefore, from the point of view of psycholinguistics, whole systems of verbal strategies and tactics should be developed, and new speech forms should be proposed that would help to get out of a difficult psychological state.In practice, this is not the case. Often, the media themselves provoke such informative topics that negatively affect the emotional state of a person. An illustration of this can be demonstrated from the point of view of political Psycholinguistics (Sterling, Jost \& Bonneau, 2020): using an automated text analysis method, Twitter posts were analyzed with attention to the special style of participants in accordance with their political orientation, public mood, and the needs of recipients. Researchers have proven that the regularity of speech, the specificity of vocabulary to the requirements of the time, the escalation of the political situation through the word (in accordance with the needs of the audience) are all those psychological factors that help manipulate the consciousness of the masses. In times of social crises, changes in lexical semantics, the appearance of new language units or the correction of emotional shades in words are especially relevant, which is motivated by the need for the correct selection of such language units for a potential recipient. We decided to analyze the new words that appeared with COVID-19, and which, responding to the emotional requests of recipients, are actively replicated through the mass media. In addition, our analysis is a media and psycholinguistic cross - section of the fund of new words that have appeared in a very short time in the modern Ukrainian language. The purpose of our research, therefore, is to explain the psycholinguistic basis of media neologization, which became actively used by Ukrainians under the influence of the COVID-19 pandemic.

\section{Research methods and materials}

To find the reasons for the active functioning of language innovations in the media (and as a result - in the speech of the masses), we used the method of critical and discourse analysis (to understand the patterns of appearance and functioning of new language units in media discourse). The methodology allowed us to critically consider media content in the triad "language - media - time of functioning" (in some studies (Androutsopoulos, 2009, p.5), a fourth segment is added here "ideology"). We also partially used the system-search method, which allowed us to systematize data from information search engines. The cross-sectional research method allowed us to explain the local manipulative strategies used in the media when using language innovations related to COVID-19 (the methodology has already been tested (Zhong, Luo, Li, H., Zhang, Liu, Li, W. \& Li, Y., 2020, p.1746) previously. We have expanded the cross-sectional research areas by offering a Facebook network for analysis with extensive reposting capabilities for media publications with the topic "COVID-19".

The method of semantic and stylistic interpretations (as well as elements of psycholinguistic interpretations) was used as the main one for analyzing media contexts with neologisms caused by COVID-19. It were the methods of psycholinguistic interpretations that made it possible to distribute media contexts with new words into three groups (see Fig. 4). For objectification, the results were taken in English-language (@KyivPost; @Forbes.Ukraine.official), Russian-language (@www.rbc.ua; @podrobnosti; @GazetaVesti; @korrespondent.net, etc.) and Ukrainian-language (@tsn.ua; @hromadskeua;@pryamiy; @5kanal; @imi.org.ua; @ukrpravda; @Fakty.ICTV; @suspilne.news, etc.) official media pages on Facebook.

\section{Results and discussions}

It is the media that generates new vocabulary, actively relaying it in new media contexts. We explain the spread of neologisms in mass communication by the phenomenon of the so-called "verbal fashion" for language innovations that have saturated the media recently (extralinguistic factors). In addition, the dynamics of the language system in the media are influenced by socio-political events, economic processes, globalized technical transformations in the world, etc., to which the media reacts with a new nomination of these phenomena. The new semantics of the already well-known medical term will arise under the influence of the background knowledge of recipients. Therefore, the spread of determinologized medical units in the media is much faster than any other language resource.

The media mood of Ukrainians during the quarantine changed according to the situation with the official disease of COVID-19. Thus, news of a neutral nature about the coronavirus changed to negative at the peak of the pandemic (September-October 2020), or positive (during the reduction of the number of patients with COVID-19): "severe virus" $\rightarrow$ "death virus", social lockdown $\rightarrow$ "intellectual" lockdown, "symptoms of coronavirus" $\rightarrow$ "flu symptoms", "fighting coronavirus" $\rightarrow$ "getting out of 
DOI: https://doi.org/10.37708/ezs.swu.bg.v20i1.8

a psychological crisis", "coronanegative" $\rightarrow$ "coronapositive", etc. We see the reasons for this change (and E-search interest) in the psycholinguistic component: a recipient enters words into search engines that he subconsciously hears and constantly uses in the flow of speech (primarily drawing them from media sources). This, in turn, explains the popularity of using the derivative "corona-.." / "корона-.." in new and derived search query units: "coronavirus", "coronafake", "coronapositive", "coronanegative" (in English-language media) and "коронавірус" / "коронавирус", “короназалежність” / “короназависимость”, “коронапозитивний” / “коронапозитивный”, “коронанегативний” / “коронанегативный” (in Ukrainian- / Russian-language media) in the information space, etc.

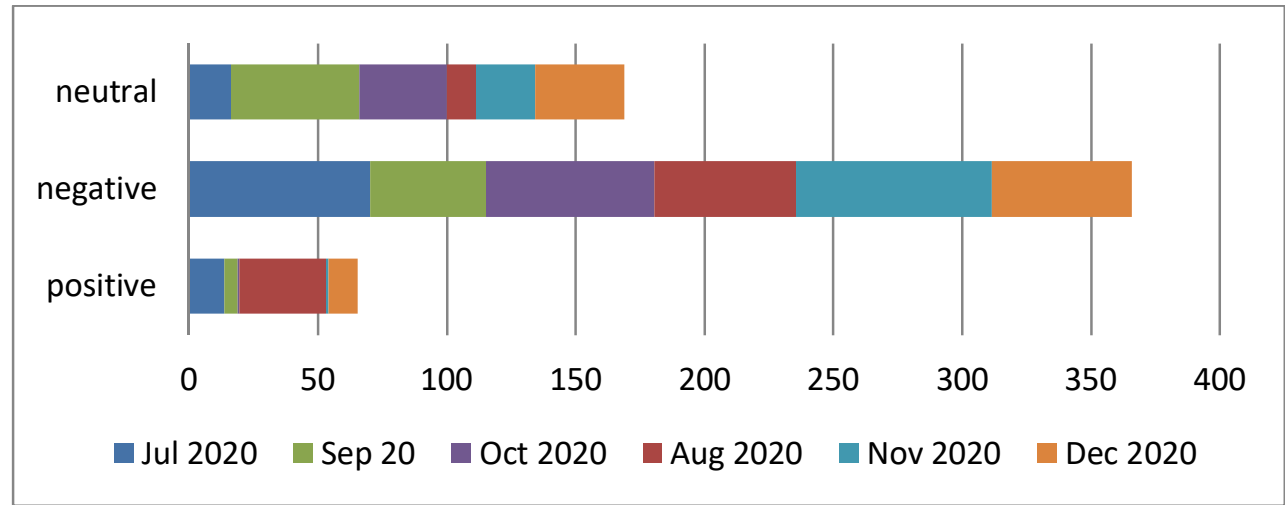

Fig. 1. Changes in the mood of Ukrainians in the media space (\%)

The popularity of global requests and "trends" for COVID-19 also seems logical. The media responds to this, adapting to the mood and requests of the information society. Note the manipulative news about COVID-19 in modern media, which is also a psychological factor in the mentioned "infodemic" (Cifuentes-Faura, 2020). In the aspect of psycholinguistics (Riles, 2019; Spears, 2021), provocative (sometimes "fake") news about COVID-19 is becoming popular among recipients, which negatively affects the flow of information. However, it is relevant, because it can be sensational. We consider it annoying in modern media communication, after all "journalists should pay attention for source selection and authentication for their news stories production" (Gans, 2004).

The dynamics of search queries is interesting (12.03.2020 - 23.04.2020): the request for coronavirus in news searches (and therefore in news headlines) has tripled, which indicates the popularity of the token in the information flow. This is also reflected in official news posts on Facebook: from information as As an alarming coronavirus resurgence sets records for confirmed cases and hospitalizations across the U.S. South and West (@KyivPost), COVID-19 approaching Ukraine = COVID-19 наближається до України (@pryamiy), The number of people infected with COVID-19 in the world is approaching 200 thousand = Кількість заражених COVID-19 у світі наближається до 200 тисяч (@hromadskeua), Coronavirus: in Ukraine the first cases of the disease = Коронавірус: в Украӥні перші випадки захворювання (@tsn.ua) to analytical Italy has placed its 60 millions residents under quarantine, as the number of coronavirus cases throughout the country continues to rise (@KyivPost), Coronavirus infection: causes of the pandemic in Ukraine = Коронавирусная инфекиия: причины пандемии в Украине (@podrobnosti), Coronavirus in Ukraine and the world: what is known as of April $23=$ Коронавирус в Украине и мире: что известно на 23 апреля (@www.rbc.ua) headlines. At the beginning of the pandemic, therefore, no language innovations were identified in the media, which is motivated by the popularity of COVID-19 barbarism itself and its counterpart coronavirus in Ukrainian-language realities. At the same time, journalists moved from the metaphorized nomination for the similarity of the virus to the crown, graphically arranged in quotation marks ("coronavirus"), to the commonly used word without quotation marks (coronavirus), and even

\#coronavirus (\#coronavirus 4 ). Such dynamics can be explained by the resonance of the language unit for colloquial communication, just as it was once with the nominations "kuchmism" kuchmism, "Maidan" - Maidan, "Heavenly Hundred" - Heavenly Hundred (in the Ukrainian realities:кучмізм, Майдан, Небесна сотня): "active development and significant axiological reorientation of the systems of nominative and stylistic means of the Ukrainian language of the late XX 
- early XXI centuries. <..> Find their very revealing expression in the system of Ukrainian word formation" (Taranenko, 2015, p.231), and first of all this concerns socially significant nominations, originating in the language. Analyzing new words in the media, we found out that most of the nominations from the medical field are explained by extralinguistic factors. Obviously, the pandemic, as well as the realities associated with COVID-19, have also made adjustments to the language system of the Ukrainian language. Despite the fact that the words appeared as barbarisms, they actively entered the use of Ukrainians, transliterating and transforming them: covid, covid (patient, case, analysis / test), coronial, coronapocalypse, coronageddon, as well as nominations related to the accompaniment of viral disease: PCR test (PCR testing), infectious lockdown, covid anti-record, quarantine (quarantine zone), etc. Interestingly, these nominations were actively used by all communicants, which is proved by our research of the media sphere (we analyzed different topics, sphere distribution by the audience of the Ukrainian media). They even drew attention to the fact that young people use these units in social networks, e.g., Instagram or Tik-Tok, using hashtags: \#covid, \#covidiot \#covi. The pandemic actually "gave" new words / phrases such as lockdown (political, economic, cultural), post-quarantine syndrome, covid-dependent, coronapositive, coronababy (a child conceived and / or born during a COVID-19 pandemic), covidonomics (complex name of the economy during the pandemic), etc. And, as a result, new words that became accompanying in the covid era: zoom dependence, online work, political covid-defeat, ZeCovid = 3eKoвid, etc. (see fig. 2). The psychological factor of using such nominations is dominant, because the communicant, using them, actually remains in the topic of communication, which is currently the background.

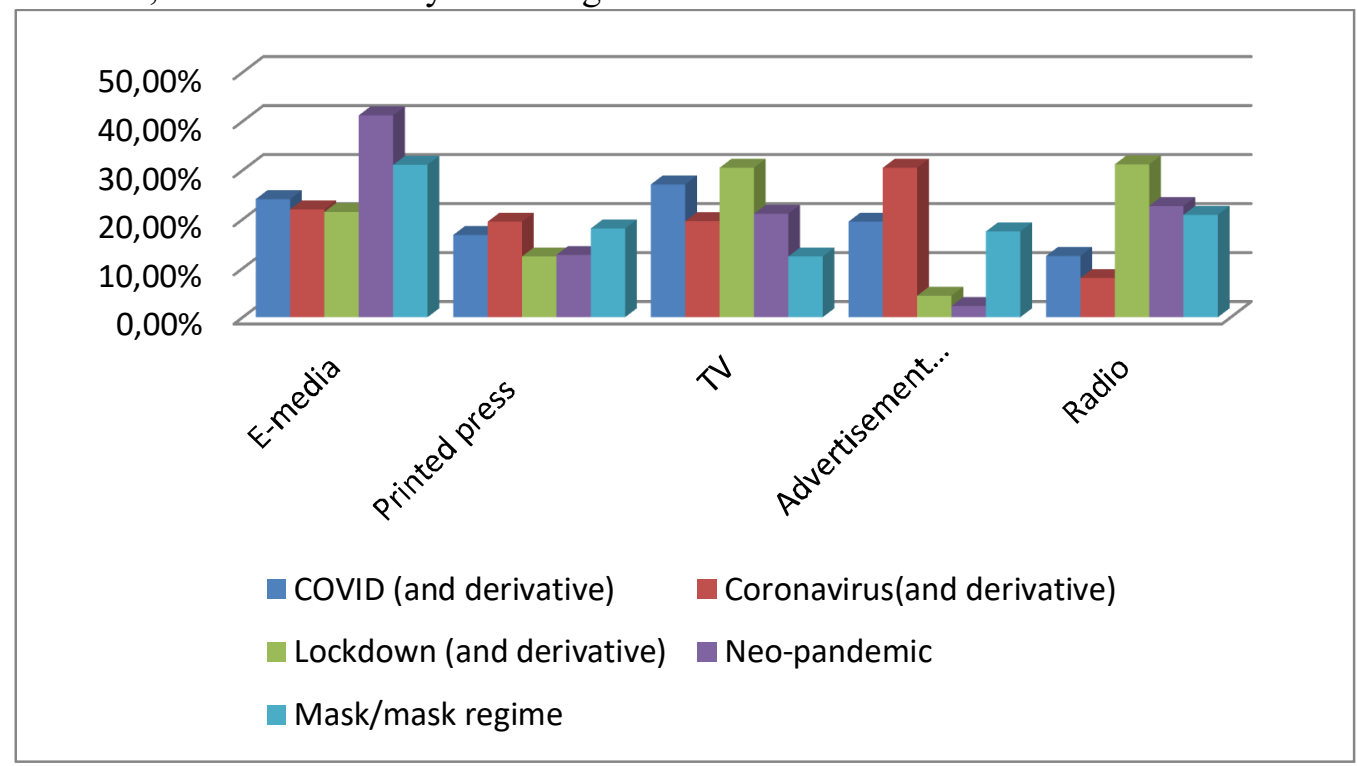

Fig. 2. Introducing new words related to COVID-19 (based on the material of the e-file for the dictionary "new words and phraseological units in Ukrainian mass media") (\%)

It is difficult to find unique words that are purely Ukrainian, because they are all of Latin origin and are actually internationalisms. This applies to COVID, coronavirus, lockdown, pandemic, etc. but we can talk about the specifics of adapting new words to the laws of the Ukrainian language, new spelling (e.g.. we see such a new nomination of a doctor working with covid patients as covidka = ковідка). Obviously, there is a new rule in spelling regarding feminitives. Neologisms in the Ukrainian media appear later, which is confirmed by our e-file to the dictionary of new words for phraseological units in mass media (2020). This can be illustrated with examples from news headlines on Facebook: $A$ new term for defining coronavirus idiots has been added to the English Dictionary $=У$ словник англійськоїмови внесли новий термін для визначення коронавірусних idiomiв (@pryamiy), "I guеss there's varying degrees of how much of a covidiot you can be,"- Kauai Mayor Derek Kawakami@KyivPost),The Institute of mass information announces a contest "catch a Coronafake!" = Iнститут масової інформаиії оголошує конкурс "Лови КОРОНАфейк!" (@imi.org.ua), Wuhan Virus "registered" forever, but will be homeless dangerous - virologist = Уханьский вирус "прописался" навсегда, но станет менее опасным - вирусолог (@GazetaVesti), Coronaphobia: what Ukrainians are most afraid of today = Коронафобія: чого найбільше бояться україниі сьогодні 
DOI: https://doi.org/10.37708/ezs.swu.bg.v20i1.8

(@5kanal), Covidiot conspiracists slammed for sharing 'fake' video of empty hospital (@Forbes.Ukraine.official).

New words also appear in the lexicon of Europeans (we even noticed a certain universalization in this issue regarding the English language as an international donor of new words). So, in the Urban dictionary of slang, the first and most popular media neologisms among recipients, such as covidiot (a person who stocks up on goods during quarantine) or coronabrain (the brain of coronavirus), appear in mid-March (Fig. 3); English scientists have even invented a special definition for a special language during the COVID-19 pandemic - coronospeak. In the Ukrainian media, these language innovations were picked up in April. This trend is a natural process for the language and is associated with the dynamics of the Ukrainian word in mass communication, the maximum objectification of the real picture of the life of the Ukrainian language in media communication.

\begin{tabular}{|c|c|}
\hline TOP DEFINITION & APR 20 \\
\hline Covidiot & coronabrain \\
\hline $\begin{array}{l}\text { Relating to the } 2020 \text { Covid- } 19 \text { virus: } \\
\text { Someone who ignores the warnings regarding public health or safety. } \\
\text { A person who hoards goods, denying them from their neighbors. }\end{array}$ & $\begin{array}{l}\text { Basically when you lose your shit because of } \\
\text { coronavirus induced panic and can't maintain } \\
\text { a sense of focus due to constantly } \\
\text { overwhelming circumstances. }\end{array}$ \\
\hline $\begin{array}{l}\text { Did you see that covidiot with } 300 \text { rolls of toilet paper in his basket? } \\
\text { That covidiot is hugging everyone she sees. }\end{array}$ & $\begin{array}{l}\text { Tony can't remember shit these days with } \\
\text { covid-19 and all, he forgets what he's doing in } \\
\text { the middle of the task, they say he got a } \\
\text { coronabrain. }\end{array}$ \\
\hline \#coronavirus \#covid-19 & $\begin{array}{l}\text { \#coronabrain coronavirus } \\
\text { by basicbitch89 March 19, } 2020\end{array}$ \\
\hline
\end{tabular}

by you'reandidiot March 16, 2020

Fig. 3. Slang frequency of new units associated with COVID-19 (source: https://www.urbandictionary.com/)

In the Ukrainian media, these new tokens are also used with psycholinguistic markers: Life on credit. What does "covidiot" Elon Reeve Musk = Жизнь в кредит. Что делает "ковидиот" Илон Mack (@korrespondent.net),Covidiot conspiracists slammed for sharing 'fake'video of empty hospital (@Forbes.Ukraine.official), The word "covidiot" originated from the coronavirus. What does it mean = Через коронавірус виникло слово “ковідіот”. Щовоно означає (@tsn.ua). Apparently, journalists have also started looking for new language forms to refer to COVID-19 in order to remain popular and cited among potential recipients. Accordingly, under the influence of information saturation of the market, competitiveness and manipulativeness, new words caused by COVID-19 appear. And this applies primarily to internet communication, which has become a media Super-sphere today, in which the use of neologisms is particularly relevant. We agree with the opinion that "the adequacy of interpretation of internet texts is directly dependent on the experience of using and internet activity: the more time a respondent spends online, the more accurate their interpretation of internet texts" (Akimova \& Aleksandrenko, 2019, p.25). The internet space responds much faster to social transformations, and therefore the emergence of language innovations related to COVID-19 is also logical (we note that we recorded them in the Facebook feed on the official pages of media channels). We have conditionally divided the collected language innovations into three groups related to several psychological reasons (the need to name new phenomena and evaluate a certain situation through words) and the spread of these neologisms in the media: (1) language innovations help to designate people who relate to COVID19 with different emotions - designating such persons: Corona-positive, Corona-dependent, Coronaanxiety, COVID-neighbors, etc. (manipulation of such units in the media will be the greatest, which is associated with the phenomenon of fear during the pandemic period); (2) the neologism is used for a negative / positive assessment of what accompanies COVID-19 (these are, on the one hand, nominations with a negative designation of the disease, on the other hand, nominations with a positive connotation, which is associated with self-isolation and gradual recovery from the psychological crisis): coronapanic, COVID-isolation, corona-art, corona-phobia, etc.; (3) the COVID-19 nomination in the direct meaning and the search for new synonyms, which is motivated by a banal reason - avoiding tautology in media texts (journalists do not want to abandon this concept, explaining this by the popularity of news using the COVID-19 nomination in media contexts). Such neologisms can occur as part of the formed word - forming nests with the components corona..-, ..-COVID, using prefixes and/or suffixes, as phrases in the form of periphrases. Accordingly, the analyzed material allows us to divide language 
DOI: https://doi.org/10.37708/ezs.swu.bg.v20i1.8

innovations in the media into three groups: with positive $(+)$, negative $(-)$ and neutral $(0)$ connotations, which are manifested as a consequence of the "verbal fashion" for words associated with COVID-19. All three reasons are key in the emergence and further functioning of new words related to COVID-19 in the lexicon of Ukrainians through the media.

(1) Speaking about the first group of new words that unites people associated with COVID-19, we will emphasize three types of such a nomination:

(a) people who are carriers of COVID-19 and / or are infected with the virus: Covid-positive, COVID-carrier, COVID-carrier, coronababy, coronapositive, coronavirus, etc. see Facebook: Pregnancy and childbirth of Covid-positive women in the Rivne region= Вагітність $і$ пологи Covidпозитивних жінок на Рівненщині (@ukrainianradio), Люди можуть бути COVID-носіями без клінічних проявів = People can be COVID-carriers without clinical manifestations (@vgorode), Covid-carrier detained by border guards = Носителя COVIDa задержали пограничники (@news112ua), Coronapositive in Ukraine is becoming more = Коронапозитивних в Україні стає більше (@tsn.ua),565 patients a day - there are more coronavirus cases in the country=565 xворих на добу - коронавірусних в країні стає більше (@Fakty.ICTV), etc.

(b) people who are socially isolated after returning from abroad: COVID-isolated, COVIDneighbors, observed, "sanzharivtsy" in a nеw way = "санжарівиі" на новий лад, etc. See Facebook: In the Khmelnitsky region COVID-isolated more than 3 thousand people $=$ В Хмельницкой обл. COVID-изолированные больше 3 тыс. чел. (@news112ua), What is the risk of COVID-neighbors? = Чим ризиковані COVID-cycidu? (@ukranews), Observed in "Kazatsky" at night left the hotel= Обсервовані в "Казацькому" вночі виїхали зготелю(@hromadskeua), "Sanzharovtsy" are left in the hotel "Kazatsky" in Kyiv = "Санжарівиів" на новий лад залишили в готелі "Козацький" у Києві (@novyny), etc.

(c) categories of doctors fighting COVID-19. Popular in the media are periphrases such as those who are in the fight against coronavirus $=$ mi, хто в бою з коронавірусом, fighters against COVID19 = бориі з COVID-19, angels fighting COVID = ангели, що борються з COVID, on the front line with COVID-war = на передовій з COVID-війною, etc. See Facebook: Second Front, or those who are in the fight against coronavirus = Другий рронт, або ті, хто в боюз коронавірусом(@ukrpravda), How many angels fighting COVID left us in 2020= Скільки ангелів, щьо борються з COVID, пішли вid нас 2020 року (@ukranews), etc. Such nominations have a psycholinguistic effect: to be closer to the people who help.

It should be noted that Ukrainian media communication even has peripheral constructions for the designation of persons and / or structures associated with COVID-19: COVID-commissioner (about V. Lyashko), COVID-front (about infectious diseases hospitals), COVID-soldiers (about doctors), COVIDcelebrities (about famous people infected with the COVID-19 virus), etc.

(2) A group of neologisms denotes negative and positive processes associated with COVID-19: Corona panic, COVID-isolation, coronabusiness, Corona creation, coronaphobia. See Facebook: In the new issue, they talked about the coronavirus that has flooded the whole world, in particular, Ukraine, and now it has reached Volyn= У новому випуску говорили про коронопаніку, яка заполонила увесь світ, зокрема, і Україну, а зараз дійшла і на Волинь (@vol12channel), Until the coronavirus vaccine is found, the COVID-isolation regime should become the norm = Доки не буде знайдена вакцина від коронавірусу, режим COVID-ізолячіїмає стати нормою (@novoyevremya), A dangerous "coronabusiness": in Kyiv, under the threat of weapons, 100 thousand medical masks were stolen = Небезпечний "коронабізнес": у Києві під погрозою зброї вкрали 100 тисяч медичних масок (@ukrpravda), The coronavirus has awakened corona-art in people: people who are quarantined have time to sing, dance, cook = Коронавірус пробудив у людях коронатворчість: $y$ людей, що на карантині з'явився час співати, танџювати, куховарити (@kyivtv), Football coronaphobia: an expert outlined the risks associated with the resumption of the Bundesliga = Футбольная коронафобия: эксперт очертил риски, связанные с возобновлением Бундеслиги (@footballuatv).

It was the psychological problems of getting out of the crisis that also had media illustrations in the form of neologisms: coronastress, coronomics, covidonomics, coronocrisis, coronameditation. In the media texts, new words appeared with a pronounced positive connotation to indicate the benefits during quarantine measures: We will get out of coronastress with a good mood and sports $=И_{3}$ 
коронастресса будем выходить с хорошим настроением и со спортом (@podrobnosti), Coronomics: how does the coronavirus epidemic threaten the global economy and how to get out of coronastress? = Корономіка: як епідемія коронавірусу загрожує світовій економіці та як виходити з коронастресу? (@rubryka), Covidonomics: how Belarus advises getting out of the есопотіс crisis = Ковидономика: как Беларусь советует выходить из экономического кризиса (@news112ua), A new way to distract yourself from the coronavirus - Corona meditation = Hовий спосіб відволіктися від коронавірусу - корона медитація (@ranok.ictv.ua). The influence of internet resources on the appearance of new words seems obvious to us, because the increase in the time of communicants in the internet space (especially during quarantine measures) also shows greater confidence in virtual media, social networks, and the Internet information resources. The psychology of these processes in Internet communication is described earlier (Belinskaya, 2013, p. 38-53; Khraban $\&$ Khraban, 2019). The positive / negative psychological axiology manifests itself strictly at the peak of morbidity. We did not see any humorous innovations related to COVID-19 at the beginning of the quarantine in Ukraine (which is logical due to the constant increase in infected people), but after the decline of coronavirus infection, new words with a positive connotation appear among the population. Accordingly, during the COVID-19 outbreak, new words with negative semantics appeared to a greater extent, and after the quarantine was eased, the opposite was true. It is also a psychological factor that helps the speaker not to be constantly afraid of words with a negative meaning. According to our observations, during the pandemic, media (primarily electronic) remains the main source of information / misinformation. It is the "fake" nature of news that generates a separate group of neologisms that appear in the media space (language innovations actually act as markers of time, giving an assessment of events). Accordingly, the dynamism of the information space generates "fake" news, using new words such as coronasuicide, spring-autumn COVID, COVID-20, 21, 22+n, etc., "since the existence of fake news can lead to an increase in contagion or the worsening of the disease by Covid-19" (Cifuentes-Faura, 2020, p. 149). It is recommended to solve these problems by critical analysis of media literacy (Zarocostas, 2020; Garfin, Silver \& Holman, 2020).

(3) In the search for a synonymous series for the COVID-19 nomination, journalists create new words that are imprinted in the memory of recipients. And the creation of such innovations depends on psychological factors - boredom, fear, pride, etc. "Media can be used to regulate their own psychological states" (Baryshpolets, Voznesenska\&Golubjeva, 2014, p. 37), and therefore the creation of new words for the psychological state of the recipient is also the task of a journalist. That is why we have innovations related to COVID-19, from neutral (coronavirus infection, Wuhan virus, Chinese virus) to emotionally colored (deadly covid, threat virus). See Facebook: Coronavirus infection and its consequences = Коронаінфекиія та ї̈ наслідки(@ukrpravda), Media reports about dozens of people hospitalized with suspected Wuhan virus in Chernivtsi = Mедіа повідомляють про десятки госпіталізованих з підозрою на уханський вірусу у Чернівиях (@hromadskeua), Collected recommendations from doctors in case the Chinese virus spreads throughout the country = Зібрали рекомендації лікарів на випадок, якщо китайський вірус буде ширитися всією країною (@suspilne.News),Don't panic: the death virus is spreading across Europe = Без паніки: вірус смерті шириться Свропою (@novoyevremya). Accordingly, it seems logical to present new words (phrases) associated with COVID-19 in a tabular version. We emphasize that the presented innovations are only illustrative in nature and do not reflect the media reality as fully as possible, which was not our task. However, the psychological manifestation of these language innovations, which will function in the language under the influence of extralinguistic factors, is important.

\begin{tabular}{|c|c|c|}
\hline+ (positive value) & 0 (neutral value) & - (negative value) \\
\hline $\begin{array}{ll}\leftrightarrow & \text { Covid-fighting } \\
\leftrightarrow & \text { Corona-life } \\
\leftrightarrow & \text { Coronomics / } \\
\text { covidonomiks } \\
\leftrightarrow & \text { Corona-art }\end{array}$ & $\begin{array}{ll}\leftrightarrow & \text { COVID-19 / } \\
\text { coronavirus } \\
\leftrightarrow & \text { COVID-neighbors } \\
\leftrightarrow & \text { COVID-observation } \\
\leftrightarrow & \text { covidnost } \\
\leftrightarrow & \text { Corona ininfection } \\
\leftrightarrow & \text { Corona isolation }\end{array}$ & 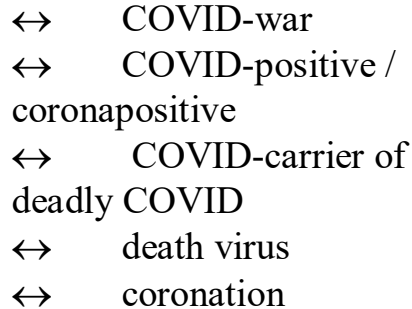 \\
\hline
\end{tabular}


DOI: https://doi.org/10.37708/ezs.swu.bg.v20i1.8

\begin{aligned} \hline & $\leftrightarrow$ covid dependence \\ & $\leftrightarrow$ Wuhan virus \\ & $\leftrightarrow$ Virus threat \\ & $\leftrightarrow$ Corona panic \\ & $\leftrightarrow$ coronavirus crisis \end{aligned}

Fig. 4. Introducing new words related to COVID-19 (by evaluation semantics)

As we can see, the axiological oppositions "good-bad" ("positive" - "negative") can also be applied to the media, which form in the minds of the mass recipient the indicated oppositions by language neologisms: "viral" - "antiviral", "COVID-fight" - "deadly covid", "coronalife" "coronadeath", "coronapositive" - "coronanegative", etc. It is noticed that psychological axiology on a conditional scale "good-bad" concerning COVID-19 can be taken dependent: "positive $\leftrightarrow$ negative ↔ neutral”.

\section{Conclusions}

The process of neologization in the media, as the results of the study show, is rapid, and especially accelerated in times of social transformation. For Ukraine, at one time, the impetus for the emergence of language innovations was given by the events of two revolutions - Orange and Dignity. The explanation for this is logical - a new phenomenon generates new words, and the media picks them up and replicates them for a wide audience, "the most expressive neologization is reflected in the updated language picture of social reality" (Taranenko, 2015, p.19), in which media remains an effective platform for popularizing language innovations; the impact of new vocabulary on the recipient is also observed in advertising communication (Khoda, 2020).Paradoxically, the time of the revolution and the post - revolutionary period are several years. And the time of the COVID-19 pandemic is several months. Accordingly, we observe in this short period of time a large surge in media neologization: coronapocalypse, corona-art, covidiot, coronaspeck, covidonomika, coronextra, coronababy, covexit, deadlyCOVID, COVID-war, Corona panic, etc. The main reasons are psychological: from the influence on mass consciousness to the popularity of the unit among recipients. Here we also see a psycholinguistic factor - the phenomenon of the so-called "verbal fashion" to nominations of COVID19 / coronavirus and their derivatives, which came with the infection to Ukraine. Therefore, language innovations presented on the scale "neutral $\leftrightarrow$ positive $\leftrightarrow$ negative". This is a representative of the mood of the Ukrainian information society. The recipient's ability to focus on positive news (Gans, 2004, p.27) is overshadowed by fear of losing health. Both in positive and negative news, language innovations appear as psychological markers of information realities. We assume that a similar emotional model of innovations in the media will take place in the following social shifts: this trend will continue not only in Ukrainian, but also in other languages whose communicants use neo-units in their speech, which act as verbal timestamps.

\section{REFERENCES:}

Акімова Н.,

Олександренко, К. (2019)

Баришполець О.T., Вознесенська О.Л., Голубсва О.С. (2014)

Белинская Е. (2013)

Тараненко О. (2015)

Androutsopoulos, J. (2009)
Вплив досвіду користування інтернетом на особливості розуміння текстів інтернету. // Психолінгвістика, №26(1), С. 11-36. (Akimova, N., \& Oleksandrenko, $K$. Impact of the Internet Using Experience on the Peculiarities of the Internet Texts Understanding // Psycholinguistics, vol. 26(1), pp. 11-36). https://doi.org/10.31470/2309-1797-2019-26-1-11-36

Медіапсихологія: на перетині інформаиійного та освітнього просторів, Київ: Міленіум. (Baryshpolets, O., Voznesenska, O., \& Golubeva, O. Media psychology: at the intersection of information and educational spaces. Kyiv: Milenium).

Психология Интернет-коммуникации. Воронеж: МОДЭК. (Belinskaya, E. Psychology of Internet communication. Voronezh: MODEK.)

Актуалізовані моделі в системі словотворення сучасної української мови (кін. $\mathrm{XX}$ - XXI ст.). Київ: Видавничий дім Д. Бураго. (Taranenko, O. Updated models in modern Ukrainian language word formation system (end of XX-XXI centuries). Kyiv: Vydavnychyj dim D. Burago).

Medienlinguistik. Beitragfür den Deutschen Fachjourn alisten-Verband. // Research on Language in Media and Society. 
DOI: https://doi.org/10.37708/ezs.swu.bg.v20i1.8 Ball-Rokeach, S., \& DeFleur, $M$.
(1976)

Bangerter, A. (2014)

Cifuentes-Faura, J. (2020)

Gans, H. (2004)

Garfin, D., Silver, R., \&

Holman, E. (2020)

Hernández-García, I., \&

Giménez-Júlvez, T. (2020)

Jones, N., Garfin, D.,

Holman, E., \&

Silver, R. (2016)

Khraban, T., \&

Khraban, I. (2019)

Khoda, L. (2020)

Neto, M., Gomes, T. de O., Porto, F.R., Rafael, R. de M.R., Fonseca, M.H.S. \& Nascimento, J. (2020)

Peter, C., Rossmann, C., \&

Keyling, T. (2014)

Riles, J.M. (2019)

Schiff, M., Zasiekina, L., PatHorenczyk, R. \& Benbenishty, R. (2020)

Shymanskaya, O. (2020)

Spears, R. (2021)

Sterling, J., Jost, J., \& Bonneau, R. (2020)

World Health Organization. Coronavirus disease (COVID-19) Pandemic (2020)

Zarocostas, J. (2020)

Zhong, B., Luo, W., Li, H., Zhang, Q.,

Liu, X., Li, W., \& Li, Y. (2020)

Zhou X., Snoswell C., Harding

L.,

Bambling M., Edirippulige S.,

Bai X., \&

Smith A. (2020)
$<$ https://jannisandroutsopoulos.files.wordpress.com/2009/09/medienlinguistik.pdf $>$ (25.05.2021).

A dependency model of mass-media effects. // Communication Research, vol. 3, pp. 3-21.

http://dx.doi.org/10.1177/ 009365027600300101

Investigating and Rebuilding Public Trust in Preparation for the Next Pandemic. // European Psychologist, vol. 19, pp. 1-3. https://doi.org/10.1027/1016-9040/a000173 COVID-19 and Infodemics: How to Solve this Problem. // International Journal of Media and Information Literacy, vol. 5(2), pp. 145-152. https://doi.org/10.13187/ijmil.2020.2.145

Deciding what's news: A study of CBS evening news, NBC nightly news. Newsweek, and Time. Northwestern University Press.

The novel coronavirus (COVID-2019) outbreak: Amplification of public health consequences by media exposure. // Health Psychology, vol. 39(5), pp. 355-357. http://dx.doi.org/10.1037/hea0000875

Assessment of health information about the prevention of COVID-19 on the Internet. // JMIR Public Health and Surveillance, (PG-). https://doi.org/10.2196/18717

Media use and exposure to graphic content in the week following the Boston Marathon bombings. // American Journal of Community Psychology, vol. 58, pp. 4759. http://dx.doi.org/10.1002/ajep.12073

Cognitive and Pragmatic Features of the Ukrainian Army Humorous Discourse in Social Media. // East European Journal of Psycholinguistics, vol. 6(2), pp. 21-31. https://doi.org/10.29038/eejpl.2019.6.2.khr

Occasionalisms in advertizing copies (as exemplified by Slovak, Bulgarian and Ukrainian languages). // Orbis linguarum, vol. 17, n. 1, pp. 44-51. https://doi.org/10.37708/ezs.swu.v18i1.5

Fake news in the context of the Covid-19 pandemic. // Cogitareenferm. http://dx.doi.org/10.5380/ce.v25i0.72627

Exemplification 2.0. Roles of Direct and Indirect Social Information in Conveying Health Messages Through Social Network Sites. // Journal of Media Psychology, vol. 26, 19-28. https://doi.org/10.1027/1864-1105/a000103

The social effect of exposure to mental illness media portrayals: Influencing interpersonal interaction intentions.// Psychology of Popular Media, vol. 9(2), pp. $145-154$. ppm0000217

https://doi.org/10.1037/

COVID-Related Functional Difficulties and Concerns Among University Students During COVID-19 Pandemic: A Binational Perspective. // Journal of Community Health. Oct 7, pp. 1-9. https://doi.org/10.1007/s10900-020-00930-9

Metaphors of coronavirus in contemporary media. // Filologické vědomosti, vol. 1, pp. 13-17.

Social In fluence and Group Identity. // Annual Review of Psychology, vol. 72(1). https://doi.org/10.1146/annurev-psych-070620-111818

Political psycholinguistics: A comprehensive analysis of the language habits of liberal and conservative social media users.// Journal of Personality and Social Psychology, vol. 118(4), pp. 805-834. https://doi.org/10.1037/pspp0000275

https://www.who.int/emergencies/diseases/novel-coronavirus-2019 (21.05.2020).

How to fight an infodemic. // The Lancet, vol. 395(Feb. 29). https://doi.org/10.1016/S0140-6736(20)30461-X

Knowledge, attitudes, and practices towards COVID-19 among Chinese residents during the rapid rise period of the COVID-19 outbreak: a quick online cross-sectional survey. //International Journal of Biological Sciences, vol. 16(10), pp. 1745-1752. https://doi.org/10.7150/ijbs.45221

The Role of Telehealth in Reducing the Mental Health Burden from COVID-19. // Telemedicine and e-Health, vol. 26(4), pp. 377-379. https://doi.org/10.1089/tmj.2020.0068

vol. 26(4),

